\title{
PENTINGNYA KOMITMEN BISNIS INDEPENDENT BUSINESS OWNER PADA MLM ORIFLAME
}

\author{
Martin Luter Purba \\ Fakultas Ekonomi dan Bisnis, Universitas HKBP Nommensen
}

\begin{abstract}
Abstrak
Minat masyarakat untuk berbisnis semakin tinggi, ditambah dengan semakin majunya teknologi semakin membantu banyak orang memperkenalkan produknya. Ada banyak cara yang dilakukan seseorang untuk menghasilkan pendapatan salah satunya dengan berbisnis MLM Oriflame. Agar dapat mengembangkan jaringan bisnisnya IBO harus memiliki komitmen yang tinggi. Hasil dari jawaban responden mengenai komitmen bisnis menunjukkan bahwa IBO yang berkomitmen baik akan menghasilkan jaringan bisnis yang baik, yang dibuktikan dengan pencapaian bonus yang lebih baik.
\end{abstract}

\section{Kata Kunci: Komitmen Bisnis, Multi Level Marketing, Independent Business Owner, Oriflame}

\begin{abstract}
People's interest in doing business is getting higher, coupled with the advancement of technology, it is increasingly helping many people to introduce their products. There are many ways that someone can do to generate income, one of which is by doing the Oriflame MLM business. To develop their business network, IBOs must be highly committed. The results of the respondents' answers regarding business commitment show that a well-committed IBO will produce a good business network, as evidenced by the achievement of better bonuses.
\end{abstract}

Keywords: Business Commitment, Multi Level Marketing, Independent Business Owner, Oriflame

Correspondence author: Martin Luter Purba, martinpurba2oo6@gmail,com, Medan, Indonesia

\section{PENDAHULUAN}

\section{Latar Belakang Masalah}

Minat masyarakat untuk berbisnis semakin tinggi, ditambah dengan semakin majunya teknologi semakin membantu banyak orang memperkenalkan produknya. Ada banyak cara yang dilakukan seseorang untuk menghasilkan pendapatan mulai dari menghasilkan barang dan jasa, membeli produk dengan harga yang murah dan menjualnya Kembali atau menjadi Independent Business Owner (IBO) pada Multi Level Marketing (MLM).

MLM merupakan salah satu dari berbagai cara yang dapat dipilih oleh sebuah perusahaan atau produsen untuk memasarkan, mendistribusikan, ataupun menjual produknya melalui pengembangan armada pemasar, distributor, atau penjual langsung secara mandiri (independent), tanpa campur tangan dari perusahaan (Soeratman, 2002). Jika merujuk pada pendapat ini maka dapat disimpulkan bahwa IBO MLM dapat 
secara mandiri untuk melakukan strategi pemasaran untuk memasarkan produk dari MLM tersebut. Sistem MLM sangat mengandalkan IBO mereka untuk memperluas pasar penjualan mereka. MLM sangat bertumpu pada kekuatan jaringan dan penjualan langsung, yang menjadi unjung tombak perusahaan MLM adalah keanggotaan dari independent business owner (IBO). Dalam memasarkan barang IBO dianggap sebagai pelanggan dan penyalur. Seorang IBO memiliki peranan yang sangat penting bagi MLM, IBO merupakan seorang pengguna produk yang loyal dan juga seorang penjual produk yang akan menggunakan kelebihan yang dia miliki untuk dapat menjual produk MLM.

Menurut Supariyani dan Nugroho (2007) Kekuatan dari sistem penjualan langsung adalah tradisi layanan ke konsumen dan komitmen untuk pertumbuhan kewirausahaan dalam sistem pasar bebas. Sistem penjualan langsung menawarkan peluang usaha kepada mereka yang mencari alternatif untuk mendapatkan penghasilan tanpa melihat suku, jenis kelamin, tingkat pendidikan, umur maupun pengalaman. Sistem ini menawarkan peluang untuk mendapatkan penghasilan dengan bekerja secara paro waktu maupun penuh waktu. Jika melihat kekuatan dari MLM dapat juga disimpulkan bahwa MLM juga juga memiliki kelemahan, kemandirian dari IBO dan pendapatan yang sesuai dengan penjualan menyebabkan IBO dapat datang dan pergi sesuka hati mereka.

Kemandirian IBO akan memberikan efek positif bagi IBO yang memiliki ide dan semangat yang tinggi untuk memperluas jaringannya akan tetapi bagi IBO yang belum mengerti sistem MLM yang masi belum memiliki semangat untuk memperluas jaringan akan berdampak pada IBO tersebut tidak akan melanjutkan bisnis MLM tersebut. Agar IBO tetap memiliki semangat berbisnis penting bagi IBO pada MLM khususnya pada Oriflame untuk meningkat kinerja dari bisnis yang mereka bangun, IBO yang baru bergabung pada MLM harus memiliki komitmen dalam berbisnis dan tetap menjaga komitmennya pada bisnis MLM.

\section{HASIL DAN PEMBAHASAN}

Menurut Anderson dan Weitz (1992) dalam penelitiannya menyatakan bahwa komitmen didefinisikan sebagai suatu keinginan dari kegiatan untuk membangun hubungan yang stabil dengan kesungguhan untuk memberi pengorbanan guna menjaga atau mempertahankan hubungan tersebut. Harapan akan kelangsungan 
hubungan, kesungguhan untuk berinvestasi, kesediaan melakukan pengorbanan guna memperoleh keuntungan jangka panjang merupakan indikasi yang sangat penting untuk dibangun dalam suatu komitmen kerja sama.

Komitmen organisasi didefinisikan sebagai dorongan dari dalam diri individu untuk berbuat sesuatu agar dapat menunjang keberhasilan organisasi sesuai dengan tujuan dan meletakkan kepentingan organisasi di atas kepentingan pribadinya (Wiener dalam Darlis, 2002). Sedangkan menurut Mowday et al., dalam Darlis, 2002) komitmen organisasi menunjukkan keyakinan dan dukungan yang kuat terhadap nilai dan sasaran (goal) yang ingin dicapai oleh organisasi. Komitmen organisasi bisa tumbuh disebabkan karena individu memiliki ikatan emosional terhadap organisasi yang meliputi dukungan moral dan menerima nilai yang ada di dalam organisasi serta tekad dalam diri untuk mengabdi kepada organisasi (Porter et al., dalam Kartika, 2010).

Pelayanan relationship marketing, menekankan bahwa memelihara suatu hubungan adalah dibangun dengan dasar saling percaya. Seperti halnya dengan konsumen loyal terhadap merek, merupakan proses yang harus dilalui.

Menurut Husselid dan Day (dalam Ribhan, 2008); komitmen pegawai dapat mengurangi keinginan untuk melepaskan diri dari organisasi atau unit kerja. Komitmen dapat didefinisikan sebagai derajat keterlibatan relatif dari individu terhadap organisasi (Mowday, Porter dan Steers dalam Ribhan, 2008)

Derajat keterlibatan tersebut oleh mereka dicirikan melalui tiga faktor, yaitu:

1. Penerimaan yang kuat terhadap tujuan dan nilai-nilai organisasi;

2. Kemampuan untuk mengarahkan diri dan usahanya bagi keberhasilan organisasi;

3. Keinginan yang kuat untuk berkembang bersama organisasi.

Menurut (Mowday et al., dalam Wicaksono, 2006) komitmen organisasional merupakan hubungan kekuatan relatif yang luas anatar individu dengan organisasi, yang karakteristiknya dapat meliputi:

1. Adanya keyakinan yang kuat dan penerimaan atas tujuan nilai-nilai organisasi,

2. Kesediaan untuk berusaha yang sebesar-besarnya untuk organisasi, dan

3. Adanya keinginan yang pasti untuk mengetahui keikutsertaan dalam organisasi. 
Menurut Imron (2007) komitmen organisasi adalah rasa memiliki karyawan (anggota organisasi) terhadap organisasi/perusahaan untuk mewujudkan tujuan organisasi/perusahan. Tingkat komitmen yang tinggi baik secara formal struktural atau secara psikologis dapat mendorong kedekatan hubungan antara anggota organisasi dengan perusahaan tempatnya bekerja.

Komitmen menyatakan tingkat tertinggi dari keterikatan relasional, dimana komitmen akan menciptakan suatu kondisi tertentu yang menimbulkan ketergantungan, yang apabila seimbang, akan menumbuhkan rasa aman dan adanya dorongan untuk mempertahankannya. Ketergantungan yang berada pada saat yang tepat dapat meningkatkan kinerja, dimana ketergantungan berdasarkan pilihan maupun kebutuhan, memberikan landasan dimana komitmen organisasional dapat dibangun (Imron, 2007).

Soeratman (2002) menyatakan bahwa adanya komitmen dalam hubungan bisnis bagi wiraniaga dapat dibangun melalui penciptaan kepuasan atas bisnis tersebut yang meliputi kepuasan dengan produk, kepuasan margin dan kepuasan hubungan dengan wiraniaga (upline). Dalam penelitian ini faktor yang membentuk komitmen bisnis tersebut diidentifikasi kembali dalam variabel kepuasan dengan produk dan kepuasan hubungan bisnis dengan mitra atau upline sebagai variabel penduga dari komitmen bisnis IBO.

Berdasarkan teori-toeri mengenai komitmen maka IBO akan diberikan kuesioner yang harus diisi untuk melihat apakah teori tersebut berlaku untuk IBO Oriflame dan melihat bagaimana respon mereka mengenai ceramah yang diberikan.

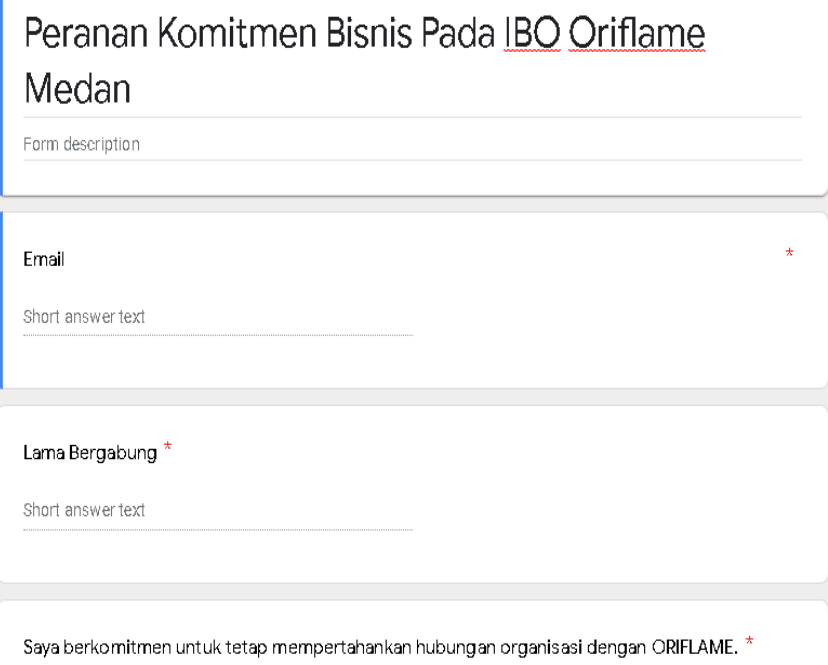




\section{Gambar 1 Contoh Kuseioner}

Pada Gambar 1 merupakan contoh kuesioner yang akan diberikan kepada IBO yang telah mendengarkan ceramah setelah acara selesai, kuesioner dibagikan melalui WhatsApp. Jawaban paling lama diterima seminggu setelah acara, dan hasilkan digunakan untuk melihat komitmen bisnis dari IBO yang diberikan penyuluhan dan melihat kemampuan pencapaian bonus dari IBO tersebut.

Tabel 1. Hasil Jawaban Responden

\begin{tabular}{|c|c|c|c|c|c|c|}
\hline Pernyataan & 1 & 2 & 3 & 4 & 5 & Total \\
\hline $\begin{array}{l}\text { Saya berkomitmen untuk } \\
\text { tetap mempertahankan } \\
\text { hubungan organisasi dengan } \\
\text { ORIFLAME. }\end{array}$ & $\mathrm{O}$ & 9,09 & 37,88 & 30,30 & 22,73 & $100 \%$ \\
\hline $\begin{array}{l}\text { Saya berusaha keras untuk } \\
\text { mengembangkan bisnis ini } \\
\text { sesuai dengan tujuan dari } \\
\text { ORIFLAME }\end{array}$ & $\mathrm{O}$ & 13,64 & 34,85 & 33,33 & 18,18 & $100 \%$ \\
\hline $\begin{array}{l}\text { Saya bersedia berinvestasi } \\
\text { dalam bisnis ORIFLAME }\end{array}$ & $\mathrm{O}$ & 22,73 & 31,82 & 30,30 & 15,15 & $100 \%$ \\
\hline Pertanyaan & \multicolumn{2}{|c|}{ Meningkat } & \multicolumn{2}{|c|}{ Tidak Stabil } & Menurun & \\
\hline $\begin{array}{l}\text { Selama } 4 \text { bulan terakhir } \\
\text { bagaimana tren bonus yang } \\
\text { anda dapatkan }\end{array}$ & \multicolumn{2}{|c|}{22,73} & \multicolumn{2}{|c|}{60,61} & 16,67 & $100 \%$ \\
\hline Pertanyaan & \multicolumn{2}{|c|}{ Berpengaruh } & \multicolumn{2}{|c|}{$\begin{array}{c}\text { Tidak } \\
\text { Berpengaruh }\end{array}$} & $\begin{array}{c}\text { Mungkin } \\
\text { Berpengaruh }\end{array}$ & \\
\hline $\begin{array}{l}\text { Apakah menurut anda } \\
\text { komitmen anda berbisnis pada } \\
\text { Oriflame berpengaruh } \\
\text { terhadap kinerja bisnis anda }\end{array}$ & \multicolumn{2}{|c|}{46,97} & \multicolumn{2}{|c|}{7,58} & 45,45 & $100 \%$ \\
\hline
\end{tabular}


Pada Tabel 1 merupakan hasil dari jawaban responden yang berjumlah 66 orang IBO yang mengisi kuesioner yang diberikan. Berdasarkan jawaban responden mengenai komitmen dalam berbisnis MLM Oriflame menunjukkan bahwa lebih dari $50 \%$ responden menjawab pada angka 3 dan 5 yang berarti berapada pada jawaban ragu-ragu dan cenderung setuju pada pernyataan yang diberikan. Jawaban ini menunjukkan bahwa IBO yang mengikuti ceramah masi belum memiliki komitmen yang kuat untuk tetap berbisnis pada MLM Oriflame.

Pada pertanyaan berikutnya mengenai bonus yang diterima menunjukkan 60,61\% IBO yang mengikuti ceramah menjawab tidak stabil. Jika melihat jawaban dari responden mengenai komitmen bisnis yang Sebagian besar cenderung ragu-ragu dan cenderung setuju pada komitmen selaras dengan perolehan bonus yang tidak stabil. Berdasarkan jawaban ini dapat disimpulkan bahwa komitmen yang baik dari seorang dalam berbisnis juga berdampak pada perolehan bonus yang akan mereka terima.

Pertanyaan terakhir mengenai pendapat mereka mengenai apakah komitmen bisnis berpengaruh pada kinerja bisnis IBO tersebut menunjukkan nilai yang hampir sama antara jawaban berpengaruh dan mungkin berpengaruh. Berdasarkan pertanyaan terbuka yang diberikan kepada responden yang menjawab mungkin berpengaruh Sebagian besar menjawab bahwa, IBO tersebut merasa bahwa upline yang memiliki strategi bisnis yang bagus juga memberikan pengaruh sangat besar bagi perkembangan jaringan bisnis downline mereka.

\section{KESIMPULAN}

Berdasarkan sosialisasi ini dapat disimpulkan bahwa kurangnya kesadaran untuk berkomitmen dalam berbisnis MLM Oriflame dapat berdampak pada kemampuan untuk memperluas jaringan menjadi lebih sulit, hal ini dapat menyebabkan kinerja dari IBO menjadi tidak maksimal.

\section{DAFTAR PUSTAKA}

Anderson, Erin and Barton Weitz. 1992., " The Use of Pledges to Build and Sustain Commitment in Distribution Channels". journal of marketing Research. Vol. XXIX. February. p.53-66

Darlis, Edfan. 2002., Analisis Pengaruh Komitmen Organisasional dan Ketidakpastian Lingkungan terhadap Hubungan antara Partisipasi Anggaran dengan Senjangan 
Anggaran. Jurnal Riset Akuntansi Indonesia. Vol. 5. No. 1. Januari, Hlm. 85 100 .

Imron, Much. 2007. Pengaruh Kapabilitas dan Komitmen yang dimediasi Kreativitas Strategi terhadap Kinerja Manajer (studi pada manajer perusahan ekspor furniture di jepara). jurnal dinamika ekonomi dan bisnis. Vol. 4. No.1. Maret. Hlm 1-20.

Kartika, Andi. 2010., Pengaruh Komitmen Organisasi Dan Ketidakpastian Lingkungan Dalam Hubungan Antara Partisipasi Anggaran Dengan Senjangan Anggaran (Studi Empirik Pada Rumah Sakit Swasta di Kota Semarang). Jurnal Ilmiah Kajian Akuntansi. Vol. 2. No. 1. Februari, Hlm 39-60.

Ribhan. 2008., Hubungan Karakteristik Individu Dengan Kinerja Karyawan Melalui Komitmen Organisasi Sebagai Variabel Mediasi (Studi Kasus Pada PT Chandra Superstore Tanjung Karang Bandar Lampung). jurnal bisnis dan manajemen. Vol. 4,No. 2. Januari. Hlm 91-110.

Soeratman, Lina. 2002., Dinamika Wiraniaga Multi Level Marketing, Jurnal Sains Pemasaran Indonesia. Volume I. No.3. September. Hlm. 257-274.

Wicaksono, Purwo Agung. 2006., Analisis Pengaruh Komitmen Bisnis Independent Business Owner (IBO) dan Penjulan adaptif terhadap kinerja Bisnis IBO dalam Multi Level Marketing (MLM). Program Studi Magister Manajemen Program Pasca Sarjana Universitas Diponegoro Semarang. Tesis. 